\title{
Extent of Information and Communication Technology Skills Possessed by Librarians in University Libraries in Anambra State, Nigeria
}

\author{
Nkamnebe, Emenike Chiemeka ${ }^{1} \quad$ Okeke, Ifeka Ejike $^{2} \quad$ Udem, Obiora Kingsley $^{2}$ \\ Nkamnebe, Chibuzor Blessing ${ }^{3}$ \\ 1.The Academy Library, Nigeria Police Academy, P.M.B. 3474, Wudil, Kano, Kano State, Nigeria \\ 2.Dept. of Lib. \& Info. Sc., Nnamdi Azikiwe University, P.M.B. 5025, Awka, Anambra State, Nigeria \\ 3.University Library, Paul University, P.M.B. 6074, Awka, Anambra State Nigeria
}

\begin{abstract}
Persistent innovations and advances in Information and Communication Technology have substantially modified the way information is acquired, processed, stored, retrieved, and communicated. This has consequently changed the ways the library, which is visibly and significantly placed in the profession of information management operates, hence creating the need for library and information professionals to be sufficiently skilled in ICT operations which are now necessary for effective information services delivery. However, users are seemingly starved with services which the library professionals are expected to deliver through the use of ICTs. This implies that librarians are possibly not conversant with ICTs that they might be unable to respond to users' needs promptly and render excellent library service to users as well. This is an ugly situation and may likely bring discredit to librarians and library profession in this $21^{\text {st }}$ Century. This study therefore surveyed extent of Information and Communication Technology skills possessed by librarians in the universities in Anambra State, Nigeria. The research design adopted for this study is descriptive survey. The population consists of thirty-three (33) librarians in the five universities in Anambra State. Population was small hence, the whole subjects were studied. Two instruments - achievement test and questionnaire were used for data collection. Data obtained were analyzed using simple percentages, frequencies, and mean rating. Findings of the study include: Librarians in the universities in Anambra State are weakly skilled in ICTs hence their overall average percentage score in ICT skills was $58.3 \%$. Their average percentage scores in dimensions of ICT are as follows: Basic Computing $83 \%$, File Management 71\%, Word Processing, 76\%, E-mail operations 54\%, Automated Cataloguing and Classification/use of OPAC 42\%, use of Library Automation Software 56\%, use of the Internet/WWW 61\%, Information Search and Retrieval 62\%, Presentation using Microsoft Power Point, 40\%, Database Creation/Management 38\%. Average percentage scores showed that librarians are highly-skilled in Basic Computing, Word Processing, and File Management and are moderately-skilled in Information Search and Retrieval, Internet and World Wide Web. They are weakly-skilled in Library Automation, E-mail operations, and are not skilled in Automated Cataloguing and Classification/use of OPAC, presentation using Microsoft Power Point, Database Creation/Management. Challenges militating against librarians' ICT skills acquisition were identified and solutions were proffered.
\end{abstract}

Keywords: Information and Communications Technologies, skill, Information and Communications Technologies Skills, University Library.

\section{Introduction}

Sustained advances in Information and Communication Technology (ICT) have significantly changed the way information is acquired, processed, stored, retrieved, and communicated. This has invariably influenced the ways the library, which is conspicuously and significantly placed in the profession of information provision and delivery operates. Hence, ICTs have become essential or indispensable tools in library operations. This prompts remark by Unagha, Osuigwe \& Ugocha in 2014 that the application of Information and Communication Technologies (ICT) to library operations in this $21^{\text {st }}$ Century has remained inevitable, incontestable and incontrovertible. Libraries, observed Achugbue, Uwaifo, \& Igun, (2015) have undergone a significant change in the past two decades due to the application of information technologies in automated cataloguing, circulation systems, online information retrieval, electronic document delivery, and CD-Rom databases. This development, according to Anyoku (2012) entails that a large part of librarian's responsibility in the $21^{\text {st }}$ Century involves working with computers. This, Anyoku revealed, has led to additional skill requirements.

Acquisition of the necessary skills is the driving force, and hence plays a towering role in the application and utilization of Information and Communications Technologies for effective and efficient library and information services delivery. For the fact that librarians are the link between information resources and user's need (Achugbue, Uwaifo, \& Igun, 2015), it is of great relevance that librarians are well-familiarized with Information and Communications Technologies, and possess the rudimentary knowledge of computers (Eklof \& Hellebore, 2009). According to Ademodi \& Adepoju (2009), the issue of skill acquisition and competence in the 
use of ICTs is essential, especially in the information age we are currently in. Ademodi \& Adepoju hence advocated that librarians must acquire competence to be relevant in their profession, in which nearly all roles and responsibilities are performed with the use computers.

Since the inception of this millennium, Library and Information Science scholars are believed to have, through publications acquainted library and information science practitioners of the need to be ICT-compliant, having acknowledged ICTs' sustained advances and its incontestable influence on library practices and operations. Against these warnings however, librarians' ICT skills level seem to be low still. Pilot investigations on librarians in university libraries in Anambra State, Nigeria, hence revealed that their ICT skills level seemed to be low. This confirms Osagie report in 2009 that there was lack of adequate number of professionals that are highly-skilled in the use if ICTs for acquisition, processing, and dissemination of information in a most efficient and cost-effective way. This also corroborates Anyoku's observation in 2012 that despite the importance of Information and Communication Technologies to the present day information delivery, most reports and studies ascribe low computer literacy to librarians in Nigeria. This situation arouses worry and concern, especially now that ICTs have become extremely indispensable, or even unavoidable in information sourcing, acquisition, processing, storage and dissemination. Against this background therefore, it is most imperative to conduct an investigative study into the extent of ICT skills possessed by librarians in the universities in Anambra State. This is the gap this study intends to fill.

\section{Literature Review}

Apparently, Information and Communication Technology (ICT) is a wide concept and therefore somewhat difficult to define at present (Anaehobi, 2007). Although there is overflow of definitions, swift enhancements in this area of technology are observed to have made its definition volatile or unpredictable. This agrees with Ebijuwa's report in 2005 that at this moment, there is no clearly defined and well-understood field of ICT and this could be attributed to the universality of information processes, the number of sciences, technologies and disciplines from which it draws, and the varieties of backgrounds of those concerned with them.

Apparently, librarians have exerted much effort defining the term ICTs that they should, at this moment hold back from defining the term and make efforts to acquire the skills, and also know how to apply these skills in their daily routine operations considering the fact that they are in the frontline of information management. For the purpose of literature expansion however, definitions from some schools of thought are considered here. Hence Anyakoha (2005) defined ICTs as the electronic means of capturing, processing, storing and disseminating information. Similarly, a Jos-Carnegie Partnership Project (2006) defined ICT as an umbrella term that includes communication infrastructure, physical equipment, hardware, software, and application. According to Omekwu (2006), ICTs are basically the scientific integration of information technology and communication systems for the transmission of information in multimedia formats. The term therefore is the conjunction of Information Technologies and communication technologies for the purpose of information location, acquisition, processing, storage, and dissemination.

Proficiency in the application of Information and Communication Technology in the university libraries for effective services delivery is directly connected with the extent of skill librarians possess in this area. The Council of European Professional Informatics Societies (CEPIS, 2005) defined skill as the knowledge and experience needed to perform a specific task or job, or capabilities of an individual, definable by content, to be acquired and activated through related professional training. In this context, according to CEPIS, capabilities are the physical or psychological attributes of an individual to be applied in activity-related approaches. The New International Webster's Comprehensive Dictionary of the English Language (2010) described skill as the familiar knowledge of any science, art, or handicraft, as shown by dexterity in execution or performance, or in its application to practical purposes. Laconically, the freedictionary.com defined skill as proficiency, familiarity, or dexterity that is acquired or developed through training or experience. For librarians to effectively and efficiently perform their professional jobs at this period of high expectations from them, they should possess appreciable level of ICT skills.

Researchers have identified ICT skills expected to be possessed by ICTs-skilled person, and hence, ICT-skilled librarian. These skills are very essential for managing and operating libraries in this $21^{\text {st }}$ Century. These skills according to Mazumda, (2007) cited in Anyoku, (2012) can be compartmentalized into two broad classes:

First are skills required to use computer and information technological tools. These include skills for using software application programmes e.g. word processing tools, graphic design tools, presentation software, web development, scanning techniques, database creation and maintenance, software installation skills and knowledge of hardware basics and troubleshooting. The second category includes skills for using the internet and computer communication networks such as skills to search and retrieve 
data effectively on the web environment, networking skills, and web 2.0 skills. (Mazunda, 2007; Anyoku, 2012 p.1).

Also, technology core competencies library professional should possess, as identified and adopted by the California Library Association - CLA (2005) are presented as follows:

\section{Hardware}

- Parts of your computer

$>$ Identify Computer, Monitor and drives (floppy drive, CD drive, USB port)

$>$ Start-up a workstation (power buttons, logins passwords)

$>$ Shut-down a workstation (power buttons, sequence, what equipment needs to be shut down or left on)

$>$ Use the mouse (left-click, right-click, double-click, drag), keyboard (function keys and necessary shortcuts), and other peripheral devices attached to your computer (like a monitor, scanner, or speakers).

- Printers

$>$ Start-up and shut-down the printer (power buttons, sequence)

$>$ Load paper and cartridges

$>$ Clear a paper jam

- Photocopiers, telephones, fax machines

Software

$>$ Operate and perform basic troubleshooting for these machines

\section{- Word Processing}

$>$ Create, format, save, open, and print a document

$>$ Change font style and size, cut and paste, bold, italicize, underline, and center text

$>$ Understand print preview

- Web Browsers

$>$ Understand web browser functions such as back, forward, home, print, and print preview

$>$ Understand URLs

- E-mail

$>$ Compose, address, send, receive, open, reply, forward, delete

$>$ Send and receive attachments

$>$ Re-send bounced messages

$>$ File messages in a folder system

- Operating System

$>$ Find and launch applications from the desktop or menu

$>$ Toggle between different windows using the taskbar

$>$ Resize, minimize, and maximize windows

- Files and Folders

$>$ Understand the differences between files and folders

$>$ Make a new folder, delete a folder

$>$ Copy and paste, drag and drop within files and wholefiles/folders

$>$ Open, save, or delete files or folders

$>$ Store/back-up files on floppy disks, CDs, flash drives, andsimilar removable media

\section{Security}

$>$ Knowledge of file extensions and how they are used by the computer

- Know what security software is used on staff and public computers and how it protects the computers

- Identify spam

- $\quad$ Be aware of the potential security and privacy threats while using email and the Internet (including cookies, downloading malicious files, unsecured communications, viruses, e-mail hoaxes, spyware, adware, and phishing)

\section{Troubleshooting}

- End non-responsive programs

- Reboot the workstation

- Understand cables, power cords, and switches on all equipment

- Know where to get help or technical support 


\section{Library Resources}

- Be familiar with and able to locate the library's technology-related policies \& procedures

- Be familiar with the library's intranet, if applicable

- Be familiar with the library's e-resources

- Know the webpage address for your library

- Know what resources can be found on your library homepage

- Know the webpage address for the library's catalog

- Know how to search by author, title, keyword, and subject in

- the catalog

In addition to these, the California Library Association (CLA) identified Additional Targeted Competencies for Reference, Instructional, and Management staff. They include:

Software

- Word Processing

$>$ Control layout using tables and columns

- Spreadsheet

$>$ Create and modify a spreadsheet

- Multimedia

$>$ Create a multimedia presentation

- Web Browsers

$>$ Understand different web browsers (Internet Explorer, Safari, Firefox)

$>$ Add, use, and edit bookmarks in web browser

$>$ Change the default homepage in web browser

$>$ Clear temporary internet files and clear history in web browser

$>$ Print all or part of a webpage

Search Skills

$>$ Understand media players \& other plug-ins encountered online

- Search the internet using two or three different search engines or directories

- Understand and use Boolean and proximity searching

- Evaluate availability, authority, credibility, and currency of online resources

- Understand copyright and fair use rules as related to electronic resources

\section{Public Computers}

- Understand the set-up, limitations, and security on the public computers

- Understand use of filtering software on public computers, if applicable

\section{Library Resources}

- Understand what online resources (e.g. databases) your library subscribes to, where they are available from outside the library, and how to use each of them

- Instruct library users in the effective use of the library's online

Resources.

Librarians should therefore be competent in operations relating to basic computing, file management and information storage, word processing, electronic mail, internet and World Wide Web (WWW), database creation and management, creation of multimedia presentation using Microsoft Power Point, information searching and retrieval, use of OPAC, library automation, systems troubleshooting and maintenance, security issues relating the Internet, Library 2.0 and social media. Efficiency, versatility, and competency in these skills, is fundamental to the continued relevance and significance of the information professionals and the library in the university environment in this $21^{\text {st }}$ Century.

University library is a form of academic library Aina (2004). It is instituted to help actualize the objectives of the university by serving as the gateway to teaching, learning and research. Ekere (2006) concurred that the main purpose of the university library is to support the objectives of the university which is to promote teaching, learning and research. Reitz (2004) described university library as a library or library system established, administered and funded by a university to meet the information, research, and curriculum needs of its students, faculty and staff. The importance of library for teaching, learning and research in academic setting 
cannot be overemphasized. Toye (1985) cited in Osagie (2009) buttressed this importance when he asserted that if we have no laboratories and we lack the funds to recruit staff, the enterprise of teaching in universities could continue if we had a well stocked library. In consonance with Toye's view, Amali (2004) cited in Osagie (2009) posits that:

the university library constitutes the keynote of teaching, learning and research. It is the heart and lifeblood of the university and no other single human factor is closely related to the quality of university education. Further more [sic], it should be noted that a quality university education is impossible without a quality university library (p. 131).

It is therefore incontrovertible that the university library is an essential arm of the university. It is accorded this recognition because it ensures that the mission, goals, and objectives of the university are achieved (Osagie, 2009). The significance of the university library cannot be divorced from the goal of the university. This underscores the reason Osagie maintained that:

... the quality and effectiveness of academic programmes of a university are measured in part by the quality of the library. During accreditation exercise of a programme if

the library is scored less than 70\% but all other components are scored $100 \%$ that programme will not get full accreditation... (p. 131).

In view of this, Aguolu (1989) posited that the university library is the most important organ in the university because academic worth, intellectual vitality and effectiveness of any university depend largely upon the state of the health and excellence of its library, which is its lifeblood.

However, the library may fail in this enormous responsibility it anchors in this $21^{\text {st }}$ Century if it does not shift from the traditional paradigms of information delivery to new paradigms created by the modern technologies. ICTs have changed every library operation; hence, Nwosu in 2008 declared that with the advent of ICTs, there has been a radical change in the library system and its operations and services. Nwosu further averred that the new and emerging technologies challenge the traditional library operational techniques and services, and the way a library of this century is managed. Observably, this development has created alertness and responsiveness among librarians. This is substantiated by Osagie' report in 2009 that:

the convergence of ICT and its implications for library service in academic libraries have received the widest attention among the practitioners of library and information science. No library can be relevant in this modern age, the era of ICT without access to Internet (p. 138).

Opportunities offered by advances in ICTs, with regard to universal and limitless access to information cannot be fully exploited in university libraries if librarians are not sufficiently conversant with ICTs; hence the urgent need for librarians to improve their ICT skills.

\section{Empirical Studies}

Ani, Atseye, and Esin in 2005 declared that suitably qualified personnel are required for the application of ICT in the library sector of the Nigerian economy in support of national development. In agreement with this assertion, scholars in Library profession have diversely expressed the importance of ICTs in information services delivery in the library, and have accordingly warned library practitioners to improve their ICT skills. Nevertheless, in 2012, Anyoku lamented that despite the importance of ICTs to the present day information delivery, most reports and studies still ascribe low computer literacy to librarians in Nigeria. This suggests that at this moment, librarians' ICT skills level seems unimproved yet. Librarians seem to be deficient in operations involving ICTs. The ensuing empirical studies by Adedoyin, 2005; Adedoyin, 2006; Kari, 2006; Ajidahun, 2007; Ademodi and Adepoju, 2009; and Anyoku, (2012) and Ansari (2013) authenticate the above assertions.

Adedoyin in 2005 studied professional librarians of 18 Nigerian universities and found out that out of 268, only 87 (approximately 32 percent) were ICT literate, implying that the remaining 181 (approximately 68 percent) were not skilled in ICT. Adedoyin (2006) in another study surveyed ICT Literacy among the Staff of West African University Libraries. The result of the findings showed that out of about 370 professional librarians, only 179 were ICT literate while the remaining 191 were ICT non-literate. This constitutes an overall percentage of 48.33percent for the literate professionals as against 51.62 percent for ICT non-literate professionals.

Also, Kari (2006) investigated the academic librarian and the Internet. The findings uncovered that librarians lack the necessary skills and knowledge, and are therefore not very keen. It also revealed that the training they have is just the basic computer appreciation.

Ajidahun (2007) studied the training development and education of library manpower in Information Technology in university libraries in Nigeria. The result of the findings showed that out of 276 professional librarians working in 20 university libraries in Nigeria, only 89 (32.24 percent) were computer literate. The result further revealed that the level of professional training in Information Technology received by the professional staff in Nigerian University libraries is generally inadequate.

Ademodi and Adepoju (2009) examined extent of computer skills among academic librarians in Ondo 
and Ekiti States, Nigeria. Findings revealed that few librarians use computers to carry out library functions, which may suggest that their computer skill is impeded. The study also disclosed that only one-third of the respondents have received formal computer training. The authors commented: "most of the librarians are computer literate but the rate of computer skill and competence is low".

Anyoku (2012) conducted a search on computer skills of librarians in Nigeria. Anyoku detected that although the findings of the research showed an improvement over previous studies' levels, some percentage of librarians still rated themselves as deficient in vital areas of computer skills.

Ansari (2013) studied ICT Skills Proficiency of Library Professionals in Universities in Karachi, Pakistan. The objectives of the study were to investigate the proficiency of ICT skills of library professionals at the universities in Karachi, Pakistan, and to find out the areas in which library professionals need to acquire ICT skills among others. Findings revealed that the library professionals in universities in Karachi, Pakistan are not equally proficient in all areas of ICT skills. The majority are moderately proficient.

\section{Objective of the Study}

This study seeks to determine the extent of ICT skills possessed by librarians in the universities in Anambra State, Nigeria. It also tries to uncover the constraints in acquiring ICT skills by librarians and to find out ways of augmenting the ICT skills of librarians in the universities in Anambra State, Nigeria.

\section{Research Questions}

The following research questions were put forward to guide this study:

1. What is the extent of ICT skill possessed by librarians in the universities in Anambra State Nigeria?

2. What are the constraints in acquiring ICT skills by librarians in the universities in Anambra State, Nigeria?

3. What are the ways of improving the ICT skills of librarians in the universities in Anambra State, Nigeria?

\section{Methodology}

The research design employed in the study is descriptive survey. Population of the study comprised professional librarians - University Librarians, Deputy University Librarians, Principal Librarians, Senior Librarians, Librarian I, Librarian II, and Assistant Librarians in the five universities in Anambra State, Nigeria numbering thirty-three (33). Since the population is not large, the entire subjects were studied. A total number of 33 questionnaires were distributed among the 33 librarians across the universities in Anambra State. Due to the proximity of the universities, and the number of librarians (33) involved in the study, distribution and collection of the questionnaires were prosecuted with less difficulty. All the 33 questionnaires were duly collected and analyzed.

The study was guided by three research questions. Two instruments captioned Information and Communication Technology (ICT) Skills Test/Achievement Test (ICTST), and Information and Communication Technology Skills Questionnaire (ICTSQ) were developed and deployed for the study. This two-in-one instrument has a total number of sixty (60) questions. The ICTST was sectioned into two - A and B. Section A was meant to collect the bio-data of the subjects while Section B was made up of forty (40) achievement test questions (four-options multiple choice questions, each with one correct answer) specially designed to measure the extent of ICT skills possessed by the librarians.

On the other hand, the ICTSQ was sectioned into two - A and B. Section A consists of ten (10) questions that helped to elicit data on constraints to Information and Communications Technology skills acquisition by librarians. Section B also consisted of ten (10) questions designed to extract data on ways of improving the ICT skills of librarians. Items in Sections A and B respectively of ICTSQ were structured using Four-point rating scale of SA (Strongly Agree), A (Agree), D (Disagree), SD (Strongly Disagree). Respondents were well-guided on how to complete the questionnaire. Data obtained were analyzed using simple percentages, frequencies, and mean rating. Decision rule for research question one include: Highly Skilled: 70 -100, Moderately Skilled: $60-69$, Weakly Skilled: $50-59$, Not skilled: $0-49$. For research questions 2 and 3, items to the value 2.50 and above were given positive interpretation (agreed), while items below 2.50 were given negative interpretation (disagreed). 


\section{Results and Discussion}

Table 1

Librarians' Response to Test (Achievement Test) on Information and Communication Technology (ICT) Skills

\begin{tabular}{|c|c|c|c|}
\hline Items & Frequency (No. of librarians that passed the test) & Percentage (\%) Score & Remark \\
\hline & Basic Computing Skill & & \\
\hline 1. & 23 & 70 & \\
\hline 2. & 29 & 88 & \\
\hline 3. & 27 & 82 & \\
\hline \multirow[t]{3}{*}{4.} & 30 & 91 & \\
\hline & Average Percentage & 83 & $H S$ \\
\hline & File Management & & \\
\hline 5. & 21 & 64 & \\
\hline 6. & 16 & 48 & \\
\hline 7. & 24 & 73 & \\
\hline \multirow[t]{3}{*}{8.} & 32 & 97 & \\
\hline & Average Percentage & 71 & $H S$ \\
\hline & Word Processing & & \\
\hline 9. & 25 & 76 & \\
\hline 10. & 20 & 61 & \\
\hline 11. & 29 & 88 & \\
\hline \multirow[t]{3}{*}{12.} & 26 & 79 & \\
\hline & Average Percentage & 76 & $H S$ \\
\hline & Use of Electronic Mail & & \\
\hline 13. & 6 & 18 & \\
\hline 14. & 23 & 70 & \\
\hline 15. & 27 & 82 & \\
\hline \multirow[t]{3}{*}{16.} & 15 & 45 & \\
\hline & Average Percentage & 54 & $W S$ \\
\hline & Automated Cataloguing and Classification/OPAC & & \\
\hline 17. & 6 & 18 & \\
\hline 18. & 23 & 70 & \\
\hline 19. & 12 & 36 & \\
\hline \multirow[t]{3}{*}{20.} & 15 & 45 & \\
\hline & Average Percentage & 42 & $N S$ \\
\hline & Use of Library Automation Software & & \\
\hline 21. & 22 & 67 & \\
\hline 22. & 19 & 58 & \\
\hline 23. & 18 & 55 & \\
\hline \multirow[t]{3}{*}{24.} & 14 & 42 & \\
\hline & Average Percentage & 56 & $W S$ \\
\hline & Use of the Internet and World Wide Web & & \\
\hline 25. & 27 & 82 & \\
\hline 26. & 22 & 67 & \\
\hline 27. & 16 & 48 & \\
\hline \multirow[t]{3}{*}{28.} & 16 & 48 & \\
\hline & Average Percentage & 61 & $M S$ \\
\hline & Information Search and Retrieval Skill & & \\
\hline 29. & 23 & 70 & \\
\hline 30. & 15 & 45 & \\
\hline 31. & 19 & 58 & \\
\hline \multirow[t]{3}{*}{32.} & 25 & 76 & \\
\hline & Average Percentage & 62 & $M S$ \\
\hline & Presentation Using Microsoft Power Point & & \\
\hline 33. & 10 & 30 & \\
\hline 34. & 5 & 15 & \\
\hline 35 . & 23 & 70 & \\
\hline \multirow[t]{3}{*}{36.} & 15 & 45 & \\
\hline & Average Percentage & 40 & $N S$ \\
\hline & Database Creation and Management & & \\
\hline 37. & 23 & 70 & \\
\hline 38. & 7 & 21 & \\
\hline 39. & 8 & 24 & \\
\hline \multirow[t]{3}{*}{40.} & 12 & 36 & \\
\hline & Average Percentage & 38 & $N S$ \\
\hline & Overall Average Percentage Score & 58.3 & $W S$ \\
\hline
\end{tabular}

Table 1 shows both the overall average percentage score of the librarians' Information and Communication Technology (ICT) skills along with the scores of the dimensions of ICT covered based on the forty (40) achievement test questions. As indicated in the Table 1, items 1-4 cover questions on basic computing, items 5-8 cover questions on file management, items 9-12 cover questions on word processing, items 13-16 cover questions on use of electronic mail (e-mail), items 17-20 cover questions on automated cataloguing and 
classification/use of OPAC, items 21-24 cover questions on use of library automation software, items 25-28 cover questions on use of the Internet and World Wide Web, items 29-32 cover questions on information search and retrieval, items 33-36 cover questions on presentation using Microsoft Power Point, items 37-40 cover questions on database creation and management. The overall average percentage score is $58.3 \%$. This suggested that librarians are weakly-killed in ICTs. This finding is in variance with the findings of Anyoku (2012) who reported an improved computer skill level for librarians in Nigeria than was reported in the past literature. However, the findings agree with the findings of Osuigwe \& Uhegbu (2012) which testified that librarians in Anambra State Library Board have more knowledge of ICTs than the skills at manipulating the ICTs tools. Knowledge is just a prerequisite of skill.

\section{Table 2}

Mean (x) Scores of the Response on the Constraints in Acquiring Information and Communication Technology (ICT) Skills by Librarians

\begin{tabular}{|c|c|c|c|}
\hline $\mathbf{S} / \mathbf{N}$ & ITEMS & $\operatorname{Mean}(\overline{\mathbf{x}})$ & Decision \\
\hline 1. & Librarians have little or no interest for ICTs & 3.12 & Agreed \\
\hline 2. & $\begin{array}{l}\text { Lack of adequate technological infrastructures to support integration of ICTs in the } \\
\text { curriculum of Nigerian LIS schools }\end{array}$ & 3.53 & Agreed \\
\hline 3. & Poor planning and implementation of ICT projects in Nigerian university libraries & 3.33 & Agreed \\
\hline 4. & Poor or negative attitudes of librarians towards ICTs & 2.52 & Agreed \\
\hline 5. & Nigerian library schools have not effectively integrated ICTs in their curriculum & 2.73 & Agreed \\
\hline 6. & Absence of policy for continuous evaluation or assessment of librarians' ICT skills & 3.24 & Agreed \\
\hline 7. & $\begin{array}{l}\text { Non-sponsorship of librarians to professional conferences, workshop, and seminar on } \\
\text { ICT skills acquisition }\end{array}$ & 2.12 & Disagreed \\
\hline 8. & $\begin{array}{l}\text { Institutions do not organize training programmes for their librarians on ICT skills } \\
\text { acquisition }\end{array}$ & 2.73 & Agreed \\
\hline 9. & $\begin{array}{l}\text { Lack of support from university authorities in providing necessary ICT facilities in } \\
\text { libraries }\end{array}$ & 3.34 & Agreed \\
\hline 10. & $\begin{array}{l}\text { Failure by library professional associations to conduct special training programmes for } \\
\text { librarians on ICT skills acquisition }\end{array}$ & 2.41 & Disagreed \\
\hline
\end{tabular}

Table 2 presents the mean responses for the possible challenges that hinder the librarians' ICT skills acquisition as reflected in items 1 to 10 . The mean responses ranged between 2.52 and 3.53. This is an indication that librarians agree that all the listed challenges hinder librarians' ICT skills acquisition drive, except in items 7 and 10 which have the mean ratings of 2.12 and 2.41 respectively, where they disagreed. Haneefa \& Shukkoor (2010), Igun (2010), Kamba (2011), Quadri (2012), Talab and Tajafari (2012) all agreed, but diversely that these factors encumber, or deter librarian's ICT skills acquisition urge.

Table 3

Mean (x) Scores of the Response on the Constraints in Acquiring Information and Communication Technology (ICT) Skills by Librarians

\begin{tabular}{|c|c|c|c|}
\hline $\mathbf{S} / \mathbf{N}$ & ITEMS & $\operatorname{Mean}(\mathbf{x})$ & Decision \\
\hline 11. & Librarians should have interest in ICTs & 3.84 & Agreed \\
\hline 12. & $\begin{array}{l}\text { There should be adequate technological infrastructures to support integration of ICTs in the curriculum } \\
\text { of Nigerian LIS schools }\end{array}$ & 3.83 & Agreed \\
\hline 13. & ICT projects in Nigerian university libraries should be well-planned and implemented & 3.73 & Agreed \\
\hline 14. & Librarians should endeavour to develop positive attitudes towards ICTs & 3.82 & Agreed \\
\hline 15. & Nigerian library schools should as a matter of urgency integrate ICTs in their curriculum & 3.71 & Agreed \\
\hline 16. & A policy for continuous evaluation or assessment of librarians' ICT skills should be put in place & 3.74 & Agreed \\
\hline 17. & $\begin{array}{l}\text { Universities and library managements should from time to time sponsor their librarians to professional } \\
\text { conferences, workshop, and seminar on ICT skills acquisition. }\end{array}$ & 3.70 & Agreed \\
\hline 18. & $\begin{array}{l}\text { Universities should regularly organize training programmes for their librarians on ICT skills } \\
\text { acquisition }\end{array}$ & 3.73 & Agreed \\
\hline 19. & University authorities should support their libraries by providing them with necessary ICT facilities & 3.74 & Agreed \\
\hline 20. & $\begin{array}{l}\text { Library professional associations should strive to conduct special training programmes for librarians on } \\
\text { ICT skills acquisition }\end{array}$ & 3.72 & Agreed \\
\hline
\end{tabular}

Regarding ways of improving librarians' ICT skills acquisition, the mean responses ranged between 3.70 and 3.84. This is a signal that librarians agree that the listed suggestions for improving librarians' ICT skills as shown in items 11 to 20 are all feasible, or viable. This validates the reports of Haliso, (2011); Satpathy \& Maharana, (2011); Unagha \& Ugocha, (2012); Susan \& Baby, (2012), and Anyoku, (2012) who concurrently agreed, but in different ways that the above propositions would help to improve librarians' ICTs skills if explored.

\section{Conclusion and Recommendations}

Based on the analysis and interpretation of the results, it was established that librarians in the universities in Anambra State are weakly-skilled in ICTs. However, they are highly-skilled in ICT dimensions as Basic computing, File management and Word processing. They are moderately-skilled in operations relating to the 
Internet/World Wide Web and Information search and retrieval. Their skills in electronic mail operations and use of library automation software are weak. Moreover, they possess no skill in automated cataloguing and classification/use of Online Public Access Catalogue (OPAC), presentation using Microsoft Power Point, and database creation and management.

In spite of the fact that lots of advocacy have been made on capacity building or skill acquisition by librarians on ICTs, librarians are still deficient in use of ICTs. Also, they are still facing challenges in acquiring and updating their ICT skills. Based on the findings therefore, the following recommendations were made:

The university library managements in collaboration with university authorities should create avenues for annual training and retraining of their librarians so as to hone their skills, and as well, keep abreast of recent advances in ICTs.

The Anambra State Chapter of Nigerian Library Association should on annual basis, organize forums different from the usual Annual General Meetings and conference and should be basically centered on ICT training.

The Nigerian Library Association through its registration council should enact law that provides that one of the conditions for conferring Chattered Librarian of Nigeria (CLN) should be proven competence in ICTs. This is because librarians who are ICT-deficient at this moment are no longer relevant.

In order to encourage self-development in ICT skills acquisition, university managements and library managements should make demonstrated competence in ICTs a principal criterion for employment and promotion of librarians.

Library managements should embark on annual assessment of their librarians in ICTs in order to ascertain their strength and weakness so as to initiate ways of sustain it if strong, and strengthen it if it is weak.

All operations in university libraries should be automated so as to encourage librarians to perform their routine operations using ICTs. This is essential for the fact that there is a direct correlation between frequency and extent of ITCs use, and the ICTs skill level of librarians.

Apparently, Information and Communications Technology is multidimensional. Due to some limiting factors, not all the dimensions of ICT were covered by the present study. This might affect the generalization of the findings. Moreover, this study was limited to universities in Anambra State - one out of the five states in South-East Geo-political Zone, Nigeria. Future studies should therefore accommodate other aspects of ICT and the new technologies as Library 2.0/3.0, and the Social Media. Also, the study should be extended to other states in South-East Nigeria and the entire six geo-political zones in Nigeria.

\section{References}

A Jos-Carnegie Partnership Project (2006).The history of information and communication technology at the University of Jos: Fab Educational Books. Accessed online on February12,2013 at www.unijos.edu.ng/.../ict/History\%20of\%20Communication.pdf

Ademodi, D. T. \& Adepoju, E. O. (2009).Computer skills among librarians in academic libraries in Ondo and Ekiti States, Nigeria. Library Philosophy and Practice. Accessed online on February12,2013at digitalcommons.unl.edu/cgi/viewcontent.cgi?article $=1273 \ldots$

Aguolu, C. C. (1984). The future of libraries and information service in nigeria. Nigerian Libraries 20, $53-70$.

Aina, L. O. (2004).Library and information science text for Africa. Ibadan, Nigeria: Third World Information Services Limited.

Akuezuilo, E. O. \&Agu, N. (2003). Research and statistics in education and social sciences:

Ani, O. N., Atseye, E. U., and Esin, J. E. (2005). Issues and challenges of globalization of library services in Nigeria in the $21^{\text {st }}$ Century. Information Development. 21 (3), 193 - 200. Available at http://hinarigw.who.int/whalecomidv.sagepub.com/whalecom0/content/21/3/193.full.pdf + html.

Ansari, M. N. (2013). ICT Skills Proficiency of Library Professionals: A Case Study of Universities in Karachi, Pakistan. Chinese Librarianship: an International Electronic Journal, 36. 72 - 84. URL: http://www.iclc.us/cliej/cl36ansari.pdf

Anyakaoha, M. W. (2005). Information and Communication Technology (ICT) in Library Services Coal City Libraries. 2, (1\&2) pp. 2- 12.

Anyoku, E. N. (2012). Computer skills set of librarians in Nigeria: confronting the stereotype. Annals of Library and information Studies. 59, 128 - 134. Accessed online on February 12, 2013 at http://nopr.niscair.res.in/bitstream/123456789/14441/1/ALIS\%205 9\%282\%29\%20128-134.pdf

California Library Association - CLA (2005). Technology core competencies for California library workers. Sacramento, CA: CLA. Available at https://infopeople.org/sites/all/files/past/2006/managing/HandoutCLA Core Competencies.pdf

Ebijuwa, A. S. (2005). Information and communication technology in university libraries: the Nigerian experience. Communicate Journal of Library and Information Science. 7(1 \&2), 23 - 30.

Ekere, F. C. (2006). Administration of academic libraries: A book of readings. Nsukka, Enugu State: UCO 
Academic Publishers Nigeria Limited.

Eklof, S. \& Hellberg, T. (2009). Strengthening the relationship between librarians and library users: a study of librarianship services and resources at the library of National University of Wawand. Unpublished PhD Dissertation, National University of Wawand.

Haliso, Y. (2011). Factors affecting information and communication technologies (ICTs) use by academic librarians in southwestern Nigeria. Library Philosophy and Practice. Accessed online on February 12, 2013 at digitalcommons.unl.edu/cgi/viewcontent.cgi?article $=1602$.

Haneefa, M. K. \& Abdul Shukkoor, C. K. (2010).Information and Communication Technology literacy among library professionals in Calicut University, Kerala. DESIDOCJournal of Library \& Information Technology. $\quad 30(6), \quad 55 \quad$-63.Accessed onlineonFebruary12,2013athttp://publications.drdo.gov.in/ojs/index.php/djlit/article/view/682/295

Igun, S. E. (2010). Working experience and librarians' knowledge of Information and Communication Technologies (ICTs) in Nigerian university libraries. Library Philosophy and Practice. Accessed online on February 12, 2013 at digitalcommons.unl.edu/cgi/viewcontent.cgi?article=1412...

Kamba, M. A. (2011). ICT Competency framework for library and information science schools in Nigeria: the need for model curriculum. International Journal of Library and Information Science. 3 (4), 68 - 80.

Accessed online on February 12, 2013 at $\quad$ www.academicjournals.org/ijlis/PDF/pdf2011/April/Kamba.pdf

Nwosu, O. C. (2008). Information and Communication Technology (ICT) at Alex Ekwueme Library, Federal Polytechnic, Oko: State of the art. Unizik Journal of Research in Library and Information Science.1(2). $31-37$.

Omekwu, C. O. (2006). Nigerian libraries and the world summit on the information society: issues, imperatives, and implications. In Ubogu, F. N.(ed). Libraries: Dynamic Engines for the Knowledge and information Society. Ibadan, Heinemann Educational Book. pp. 77 - 94.

Osagie, A. U. (2009). Change and choice: the development of private universities in Nigeria. Benin City: Rawel Fortune Resources.

Quadri, G. O. (2012). Impact of ICT skills on the use of e-resources by information professionals: a review of related literature. Library Philosophy and Practice. Accessed online on February 12, 2013 at digitalcommons.unl.edu/cgi/viewcontent.cgi?article $=1836$..

Rietz, J. (2004). Dictionary for Library and Information Science. Westport, Connecticut: Libraries Unlimited.

Satpathy, S. K. \& Maharana, R. K. (2011). ICT skills of LIS professionals in engineering institutions of Orissa, India: a case study. Library Philosophy and Practice. Accessed online on February 19, 2013 at http://unilib.unl.edu/LPP/satapthy-maharana.htm

Susan, M. K. \& Baby, M. D. (2012).Developing technology skills for academic librarians: a study based on the universities in Kerala, India. Library Philosophy and practice.Accessed online on February 12, 2013 at unllib.unl.edu/LPP/mathew-baby.htm

Singh, J. (2009). Leadership competencies for change management in libraries: challenges and opportunities. ICAL, 310 - 313.accessed online on February 12, 2013 at crl.du.ac.in/ical09/papers/indexfiles/ical51_250_732_3_RV.pdf

Talab, S. M. G. \& Tajafari, M. (2012). Impact of Information and Communication Technology (ICT) on library staff training: a comparative study. Annals of Library and Information Studies.59,7-15.accessed online on February 12,2013at nopr.niscair.res.in/bitstream/.../13914/1/ALIS\%2059(1)\%207-15.pdf

The Council of European Professional Informatics Society - CEPIS (2005). ICT-Skills Certification in Europe. Thessaloniki:

CEPIS.

Available

http://www.ictliteracy.info/rf.pdf/eSkills Certification final report.pdf

Typhoon Media Corporation (2010). The New International Webster's Comprehensive Dictionary of the English Language. USA: Typhoon Media Corporation.

Unagha, A. \& Ugocha, O. (2012). Information and Communication Technology (ICT) skills for human resources development in Nigerian university libraries. Library and information Science Digest: Journal of the Nigerian Library association Anambra State Chapter vol. 6,91 - 97.

Unagha, A., Osuigwe, N. \& Ugocha, O. (2014). Information and Communication Technology (ICT) skills for human resources development in Nigerian university libraries. Library and Information Science Digest: Journal of the Nigerian Library Association, Anambra State Chapter. 7 (1), 2014. 13 - 21. 
The IISTE is a pioneer in the Open-Access hosting service and academic event management. The aim of the firm is Accelerating Global Knowledge Sharing.

More information about the firm can be found on the homepage:

http://www.iiste.org

\section{CALL FOR JOURNAL PAPERS}

There are more than 30 peer-reviewed academic journals hosted under the hosting platform.

Prospective authors of journals can find the submission instruction on the following page: http://www.iiste.org/journals/ All the journals articles are available online to the readers all over the world without financial, legal, or technical barriers other than those inseparable from gaining access to the internet itself. Paper version of the journals is also available upon request of readers and authors.

\section{MORE RESOURCES}

Book publication information: http://www.iiste.org/book/

Academic conference: http://www.iiste.org/conference/upcoming-conferences-call-for-paper/

\section{IISTE Knowledge Sharing Partners}

EBSCO, Index Copernicus, Ulrich's Periodicals Directory, JournalTOCS, PKP Open Archives Harvester, Bielefeld Academic Search Engine, Elektronische Zeitschriftenbibliothek EZB, Open J-Gate, OCLC WorldCat, Universe Digtial Library, NewJour, Google Scholar

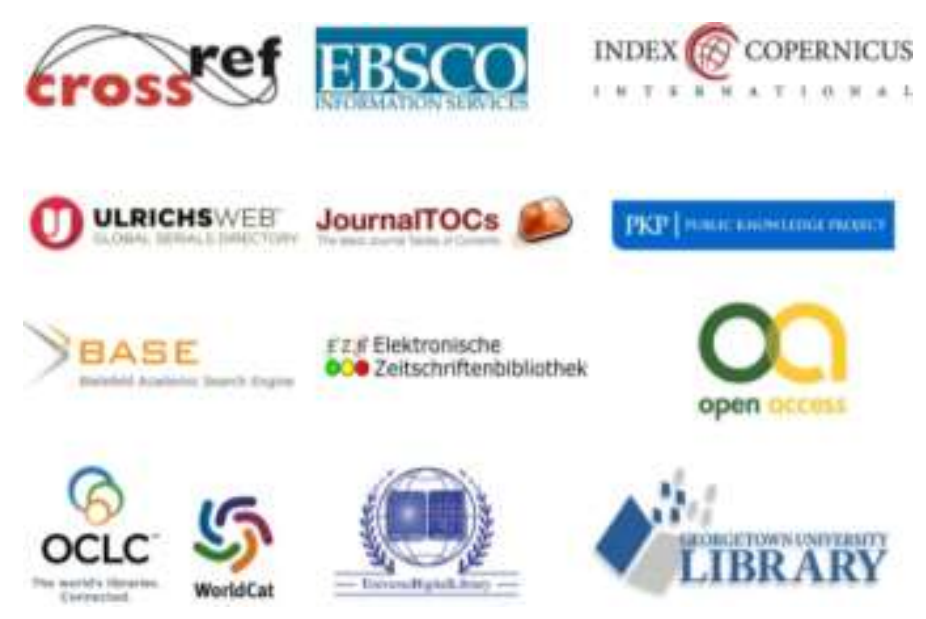

